\title{
Merdeka Belajar Kampus Merdeka terhadap Perubahan Paradigma Pembelajaran pada Pendidikan Tinggi: Sebuah Tinjauan Literatur
}

\author{
Elizabeth Simatupang ${ }^{1)}$, Indrawati Yuhertiana ${ }^{2)}$ \\ 1), 2) Universitas Pembangunan Nasional "Veteran", Jawa Timur \\ Email: elizabethsimatupang99@gmail.com
}

\begin{abstract}
Merdeka Belajar-Merdeka Campus is a policy of the Minister of Education and Culture which aims to encourage students to master various disciplines to enter the world of work. The Independent Learning-Campus Freedom Policy is in accordance with Permendikbud Number 3 of 2020 concerning National Higher Education Standards. This study uses a literature review method that allows providing other research obtained from reference materials to be used as a basis for research activities on changes in learning paradigms in higher education. The data taken in this study was through a search of several articles related to the policy of the Minister of Education and Culture which aims to provide opportunities for students to carry out learning activities in other study programs at different tertiary institutions with the learning process through face-to-face media network (online). The purpose of this research is in accordance with PERMENDIKBUD No. 3 of 2020 concerning national standards for higher education. This program is to encourage students to master a variety of competencies and this program is expected to enable students to improve the competence of graduates, both soft skills and hard skills, to be ready with the needs of the times and to prepare graduates who are superior, moral and ethical.
\end{abstract}

Keywords: Merdeka Belajar-Merdeka Campus, Educational Reform, Changes in Learning Paradigm, Higher Education

\begin{abstract}
Abstrak
Merdeka Belajar-Kampus Merdeka adalah kebijakan Menteri Pendidikan dan Kebudayaan yang bertujuan mendorong mahasiswa agar menguasai berbagai keilmuan untuk memasuki dunia kerja. Kebijakan Merdeka Belajar-Kampus Merdeka sesuai dengan Permendikbud Nomor 3 Tahun 2020 tentang Standar Nasional Pendidikan Tinggi. Penelitian ini menggunakan metode tinjauan literatur review yang memungkinkan dapat memberikan penelitian lainnya yang diperoleh dari bahan acuan untuk dijadikan landasan kegiatan penelitian terhadap perubahan paradigma pembelajaran pada pendidikan tinggi. Data yang diambil dalam penelitian ini melalui pencarian dari beberapa artikel-artikel yang terkait dengan kebijakan Menteri Pendidikan dan Kebudayaan yang bertujuan memberikan kesempatan bagi mahasiswa untuk melaksanakan kegiatan pembelajaran dalam program studi lain pada perguruan tinggi yang berbeda dengan proses pembelajaran yang melalui media tatap muka mapun secara jaringan (daring). Tujuan penelitian ini sesuai dalam PERMENDIKBUD No. 3 Tahun 2020 tentang standar nasional pendidikan tinggi. Program ini untuk mendorong mahasiswa agar bisa menguasai beragam kompetensi dan program ini diharapkan agar mahasiswa mampu meningkatkan kompetensi lulusan baik softskill maupun hard skill untuk siap dengan kebutuhan zaman dan menyiapkan lulusan yang unggul, bermoral dan beretika.
\end{abstract}

Kata kunci: Merdeka Belajar-Kampus Merdeka, Reformasi Pendidikan, Perubahan Paradigma Pembelajaran, Pendidikan Tinggi

\section{Pendahuluan}

Reformasi adalah proses perubahan ataupun pembentukan kembali suatu tatanan kehidupan yang lama, diganti dengan tatanan kehidupan yang baru. Pengertian lain dari reformasi merupakan proses pembentukan atau perubahan sistem yang telah ada pada suatu masa diganti dengan yang baru. Perubahan dan perbaikan tersebut utamanya dilakukan pada bidang politik, sosial, ekonomi, hukum dan pendidikan. Reformasi juga berarti menyempurnakan, 
memperbaiki dengan membuat sesuatu yang salah menjadi sesutu yang benar. Oleh karena itu, reformasi berimplikasi pada merubah sesuatu untuk menghilangkan yang tidak sempurna seperti melalui perubahan kebijakan institusional (Suwignyo, 2013).

Reformasi pendidikan adalah upaya perbaikan pada bidang pendidikan, Reformasi pendidikan memiliki dua karakteristik dasar yaitu terprogram dan sistemik. Reformasi pendidikan yang terprogram menunjuk pada kurikulum atau program suatu institusi pendidikan. Yang termasuk ke dalam reformasi terprogram ini adalah inovasi. Inovasi adalah memperkenalkan ide baru, metode baru atau sarana baru untuk meningkatkan beberapa aspek dalam proses pendidikan agar terjadi perubahan secara kontras dari sebelumnya dengan memperlihatkan perbedaan yang nyata apabila diperbandingkan.

Pendidikan merupakan bagian yang sangat penting bagi kehidupan manusia. Pendidikan harus mampu memberikan berbagai macam perubahan bagi manusianya. Salah satunya adalah perubahan strata sosial individu, dimana dalam memperoleh akses pendidikan harus sama dan merata. Untuk melahirkan tujuan nasional pendidikan seperti dalam hal mencerdaskan kehidupan bangsa dan pendidikan yang melahirkan keadilan sosial, hal ini tentunya harus didukung oleh sistem yang terintegrasi dan dibangun secara bersama-sama.

Dalam UU No 20 Tahun 2003 tentang Sistem Pendidikan Nasional yaitu pendidikan adalah salah satu usaha yang sengaja dan terencana untuk menciptakan suasana pembelajaran dan kegiatan pembelajaran agar peserta didik secara aktif mengembangkan potensi dirinya untuk mempunyai kekuatan spiritual keagamaan, pengendalian diri, kepribadian, kecerdasan, akhlak mulia serta keterampilan yang diperlukan dirinya, masyarakat, bangsa dan negara. Pada tingkat yang lebih tinggi yakni melalui pendidikan di Universitas/Perguruan Tinggi sebagaimana yang dijelaskan dalam Pemerintah Republik Indonesia, 2012 tentang Pendidikan Tinggi, dimana pendidikan tinggi sebagai bagian dari sistem pendidikan nasional yang memiliki peran yang strategis dalam mencerdaskan kehidupan bangsa, memajukan ilmu pengetahuan dan teknologi dengan memperhatikan sekaligus menerapkan nilai humaniora, pembudayaan serta pemberdayaan bangsa Indonesia yang berkelanjutan.

Seperti yang telah dijelaskan diatas, guna meningkatkan daya saing bangsa dalam menghadapi globalisasi disegala bidang maka diperlukan pendidikan tinggi yang mampu mengembangkan ilmu pengetahuan dan teknologi yang dapat menghasilkan intelektual, ilmuan (profesional) yang berbudaya toleran, kreatif, berkarakter tangguh serta berani membela kebenaran untuk kepentingan bangsa. Perguruan tinggi dituntut untuk dapat merancang dan melaksanakan proses pembelajaran yang inovatif agar mahasiswa dapat meraih capaian pembelajaran melalui aspek sikap, pengetahuan dan keterampilan secara optimal dan relevan.

Pendidikan Tinggi adalah lembaga ilmiah yang mempunyai tugas menyelenggarakan pendidikan dan pengajaran diatas perguruan tingkat menengah, dan yang memberikan pendidikan dan pengajaran berdasarkan kebudayaan dan kebangsaan Indonesia dengan cara ilmiah. UU No 20 Tahun 2003 tentang Sistem Pendidikan Nasional yaitu pendidikan merupakan usaha dengan sengaja dan terencana untuk menciptakan suasana belajar dan proses pembelajaran agar peserta didik secara aktif mengembangkan potensi dirinya untuk mempunyai kekuatan spiritual keagamaan pengendalian diri, kepribadian, kecerdasan, akhlak mulia serta keterampilan yang diperlukan dirinya, masyarakat, bangsa dan negara.

Pendidikan tinggi belum bisa menjadi faktor penting yang mampu melahirkan enterpreneur dengan orientasi job creating dan kemandirian. Pengangguran terdidik dari hasil pendidikan 
terus bertambah, problem pengabdian masyarakat dimana perguruan tinggi tersebut berada dirasa kurang responsif, dan berkontribusi terhadap problem masyarakat. Perguruan Tinggi juga belum sepenuhnya mampu melahirkan lulusan yang memiliki akhlak mulia dan karakter yang kuat. Melihat hal ini akar masalahnya berada pada kurikulum dan literatur yang diberikan yang tidak terkoordinasi, akreditasi kelembagaan yang tidak terukur, tenaga pendidik yang belum terakreditasi, atau masalah lainnya.

Kampus Merdeka merupakan kebijakan Menteri Pendidikan dan Kebudayaan yang bertujuan untuk mendorong mahasiswa agar menguasai berbagai keilmuan yang berguna untuk memasuki dunia kerja. Kampus Merdeka memberikan kesempatan bagi mahasiswa untuk memilih mata kuliah yang akan mereka ambil. Adanya konsep belajar merdeka tentunya bertujuan untuk memberikan keleluasaan kepada mahasiswa untuk belajar diluar kampus. Program ini diharapkan agar mampu meningkatkan kompetensi lulusan, baik soft skills maupun hard skills, agar lebih siap dan relevan dengan kebutuhan zaman dan juga untuk menyiapkan lulusan sebagai pemimpin masa depan bangsa yang unggul, bermoral dan beretika (Suhartoyo et al., 2020).

Kebijakan Kampus Merdeka ini sesuai dengan Mendikbud RI, 2020 tentang Standar Nasional Pendidikan Tinggi, pada Pasal 18 disebutkan bahwa pemenuhan masa dan beban belajar bagi mahasiswa program sarjana atau sarjana terapan dapat dilaksanakan mengikuti seluruh proses pembelajaran dalam program studi pada perguruan tinggi sesuai masa dan beban belajar dan mengikuti proses pembelajaran di dalam program studi untuk memenuhi sebagian masa dan beban belajar dan sisanya mengikuti proses pembelajaran di luar program studi. Dalam penerapannya, konsep ini nantinya mahasiswa akan diberikan keleluasaan selama dua semester pada program belajarnya untuk melakukan kegiatan diluar kelas. Konsep ini pada dasarnya menjadikan mahasiswa untuk lebih bersosialisasi dengan lingkungan diluar kelas. Agar nantinya mahasiswa secara tidak langsung akan diajak untuk belajar caranya hidup di lingkungan masyarakat, Pada dasarnya kebijakan tersebut bertujuan untuk dapat mengenalkan adanya dunia kerja pada mahasiswa sejak dini. Sehingga kemudian mahasiswa akan jauh lebih siap kerja setelah nantinya lulus dari sebuah perguruan tinggi yang tersedia.

\section{Tinjauan Pustaka}

\subsection{Reformasi Pendidikan}

Reformasi pendidikan merupakan paradigma baru tentang pemahaman pembaharuan dalam hal pendidikan, baik dalam sistem yang akan dilaksanakan serta pembelajaran yang bertujuan untuk mengembangkan potensi setiap pelaku pendidikan kepada arah yang lebih baik. Dalam hal reformasi pendidikan juga perlu diperlakukan peningkatan dalam hal peningkatan kualitas pendidikan, dengan demikian reformasi merupakan upaya untuk perbaikan dalam bidang sosial, pendidikan, politik atau agama dalam suatu masyarakat atau negara. Tujuan reformasi pendidikan adalah supaya pendidikan dapat berjalan lebih efektif dan efisien dalam mencapai tujuan pendidikan nasional. Pemerintah dan masyarakat harus mau bekerjasama demi tercapainya kualitas pemberdayaan manusia yang diinginkan, maka sistem pendidikan harus mampu menyesuaikan pula dengan tuntunan yang terkini.

\subsection{Kebijakan Pemerintah Tentang Perubahan Paradigma Mengajar di Indonesia}

Kebijakan Kampus Merdeka ditetapkan untuk mempermudah pendirian program studi (prodi) baru bagi PTN dan PTS dengan akreditasi A dan B melalui beberapa ketentuan. Sebelumnya, wewenang membuka prodi baru hanya dipegang oleh PTN-BH. Adapun proses perizinan pembukaan prodi baru untuk PTS dan PTN non-BH memakan waktu yang lebih lama. Selain 
itu, prodi yang baru dibuka hanya mendapatkan akreditasi minimum (bukan C) (Kemendikbud, 2020). Hal ini menghambat proses penyesuaian perguruan tinggi dengan kondisi industri masa kini. Untuk itu, pemerintah menetapkan program Kampus Merdeka ini agar perguruan tinggi dapat mengikuti arus perubahan dan kemajuan yang link and match dengan kebutuhan lapangan pekerjaan (Kemendikbud, 2020).

Program Kampus Merdeka juga menyoroti perubahan definisi Satuan Kredit Semester (SKS). Berdasarkan Permenristekdikti no. 44/2015, SKS merupakan takaran waktu kegiatan belajar berdasarkan proses pembelajaran maupun pengakuan atas keberhasilan usaha mahasiswa dalam mengikuti kegiatan kurikuler. Selama ini, definisi SKS terbatas pada metode pembelajaran tatap muka di dalam kelas. Akan tetapi, dalam skema yang baru, mahasiswa diberikan hak untuk secara sukarela melakukan kegiatan di luar program studi, bahkan di luar perguruan tinggi yang dapat diperhitungkan dalam SKS.

Penerapan kampus merdeka merupakan salah satu tujuan agar mahasiswa memiliki kemampuan untuk menguasai beragam keilmuan yang berguna didunia kerja nantinya. Dalam kampus yang merdeka sendiri ada empat hal yaitu mengubah PTN satker menjadi PTN BH, adanya penyederhanaan pada akreditasi perguruan tinggi, membuka prodi baru, adanya kegiatan dua semester diluar kampus. Menjadikan dunia perkuliahan agar menjadi lebih fleksibel dan juga lebih baik, tujuan utama dari program merdeka belajar adalah melepas belenggu kampus agar lebih mudah bergerak sehingga para mahasiswa mampu belajar lebih dalam mengetahui peranya sebagai mahasiswa yang diinginkan nantinya. Memberikan kesempatan mahasiswa untuk mendalami studi yang diambil dengan adanya penerapan merdeka belajar, mahasiswa diajarkan untuk lebih mendalami mata kuliah pada studi yang diambil. Hal ini tentunya berkaitan dengan Tri Dharma Perguruan Tinggi, khususnya dalam penelitian dan pengembangan, apabila mahasiswa mampu mendalami program studi yang diambil, pasti akan membawa hawa segar bagi perguruan tinggi dan tentunya bagi mahasiswa itu sendiri. Selain ilmu yang sudah didapat, pengalaman pun juga akan membuat mereka lebih maju dan memiliki pemikiran yang sangat luas.

\subsection{Paradigma Pendidikan}

Paradigma adalah sifat yang paling khas atau yang mendasar dari sebuah teori atau cabang ilmu, Istilah paradigma menjadi terkenal setelah diungkapkan oleh (Kuhn, 1996) melalui bukunya "The Structure of Scientific Revolution". Dijelaskan dalam buku ini bahwa ilmu pengetahuan berkembang dari masa awal pembentukan, setelah itu memperoleh pengakuan dan berkembang menjadi paradigma.

Robert Friedrichs merumuskan pengertian paradigma sebagai suatu pandangan mendasar tentang apa yang menjadi pokok persoalan yang semestinya dipelajarinya. Menurut (Ritzer, 1975) merumuskan pengertian yang lebih jelas lagi menurutnya, paradigma adalah pandangan yang mendasar dari ilmuwan tentang apa yang menjadi pokok persoalan yang semestinya dipelajari oleh suatu cabang ilmu pengetahuan. Lebih tepatnya adalah sesuatu yang menjadi pokok persoalan dalam satu cabang ilmu menurut versi ilmuwan tertentu. Paradigma adalah cara seseorang memandang kenyataan dalam kehidupan. Paradigma sebagai cara bertanya, cara menjawab, menentukan masalah dan memecahkannya. Di dalam paradigma terkandung berbagai nilai dan asumsi yang dijadikan dasar mengajukan pertanyaan dan menjawabnya.

Konsep tentang paradigma yang dikembangkan oleh Thomas S. Kuhn tersebut lebih diarahkan pada ilmu-ilmu alam. Paradigma dalam ilmu alam adalah tunggal, artinya pada 
waktu tertentu ilmu pengetahuan didominasi oleh paradigma tertentu. Jika paradigma yang pertama ini menjadi lemah maka terjadilah revolusi untuk mengantarkan munculnya paradigma yang baru. Dan begitu seterusnya proses yang terjadi. Berbeda dengan ilmu alam, ilmu sosial memiliki banyak paradigma. Menurut (Ritzer, 1975), menunjukkan adanya tiga paradigma yaitu fakta sosial, definisi sosial, dan perilaku sosial. Masing-masing dari ketiga paradigma ini memilik asumsi, teori, dan metode yang berbeda-beda.

Menurut (Ritzer, 1975), tentang paradigma ilmu sosial ini juga telah berkembang dalam membahas model pengembangan pendidikan. Model pengembangan pendidikan tertentu akan mempunyai implikasi pada pengembangan kurikulum, kepemimpinan, manajemen sumber daya, pengelolaan kelas dan strategi pembelajaran. Paradigma perilaku sosial akan melahirkan model (paradigma) behavioristik. Paradigma definisi sosial akan melahirkan model konstruktivistik.

\subsection{Pendidikan Tinggi}

Pendidikan tinggi merupakan jenjang pendidikan setelah pendidikan menengah yang mencakup program pendidikan diploma, sarjana, magister, spesialis, dan doktor yang diselenggarakan oleh pendidikan tinggi. Pendidikan tinggi diselenggarakan dengan sistem terbuka. Perguruan Tinggi adalah satuan pendidikan yang menyelenggarakan pendidikan tinggi dan dapat berbentuk akademi, politeknik, sekolah tinggi, institut, atau universitas.

Tujuan dari perguruan tinggi adalah mengembangkan potensi mahasiswa agar menjadi manusia yang beriman dan bertakwa kepada Tuhan Yang Maha Esa dan berakhlak mulia, sehat, berilmu, cakap, kreatif, mandiri, terampil, kompeten, dan berbudaya untuk kepentingan bangsa agar menghasilkan lulusan yang menguasai cabang Ilmu Pengetahuan dan Teknologi untuk memenuhi kepentingan nasional dan peningkatan daya saing bangsa dihasilkannya Ilmu Pengetahuan dan Teknologi melalui Penelitian yang memperhatikan dan menerapkan nilai Humaniora agar bermanfaat bagi kemajuan bangsa, serta kemajuan peradaban dan kesejahteraan umat manusia nantinya.

Fungsi perguruan tinggi adalah mengembangkan kemampuan dan membentuk watak serta peradaban bangsa yang bermartabat dalam rangka mencerdaskan kehidupan bangsa dan mengembangkan Sivitas Akademika yang inovatif, responsif, kreatif, terampil, berdaya saing, dan kooperatif melalui pelaksanaan Tridharma. Pada tingkat yang lebih tinggi yakni pendidikan di Universitas/Perguruan Tinggi sebagaimana yang dijelaskan dalam (Pemerintah Republik Indonesia, 2012) tentang Pendidikan Tinggi, dimana pendidikan tinggi sebagai bagian dari sistem pendidikan nasional yang memiliki peran yang strategis dalam mencerdaskan kehidupan bangsa, memajukan ilmu pengetahuan dan teknologi dengan memperhatikan sekaligus menerapkan nilai humaniora, pembudayaan serta pemberdayaan bangsa Indonesia yang berkelanjutan.

\section{Metode Penelitian}

Penelitian ini dilakukan dengan menggunakan Tinjauan Literature Review. Literature Review merupakan tentang teori, temuan dan artikel penelitian lainnya yang diperoleh dari bahan acuan untuk dijadikan landasan kegiatan penelitian. Penelitian yang dirumuskan dengan melakukan penelitian menggunakan Literature Review memungkinkan dapat memberikan penelitian lainnya yang diperoleh dari bahan acuan untuk dijadikan sebagai landasan kegiatan penelitian terhadap perubahan paradigma pembelajaran di pendidikan tinggi. Sumber data yang dilakukan pada penelitian ini diperoleh dari barbagai referensi melalui peraturan perundang-undangan, dokumentasi tentang kebijakan kampus merdeka dan juga penelitian- 
penelitian yang berkaitan dengan perubahan paradigma pembeljaran pada pendidikan tinggi. Tujuan dari penelitian ini adalah untuk mensintesis dan mereview literatur yang terkait dengan reformasi pendidikan di Indonesia, sehingga dapat memahami tentang kebijakan kampus merdeka terhadap perubahan paradigma pembelajaran pada pendidikan tinggi.

Pencarian dari literatur ini menggunakan database melalui elektronik yaitu google scholar dengan kata kunci "Merdeka Belajar-Kampus Merdeka" "Reformasi Pendidikan" "Perubahan Paradigma Pembelajaran" "Pendidikan Tinggi". Dari hasil penelusuran dapat menghasilkan 30 artikel penelitian. Pada tinjauan litertur review ini penulis melakukan berbagai kriteria dalam pencarian google scholar yaitu: (1) Artikel yang ditelusuri asli (bukan merupakan review penelitian), (2) Penelitian dilakukan dengan rentang waktu yaitu 5 tahun (2015-2020), (3) Artikel penelitian dilakukan dengan full-text dalam Bahasa Indonesia maupun Bahasa Inggris, (4) Mengkaji dari reformasi pendidikan, yang berfokus pada kebijakan kampus merdeka terhadap perubahan paradigma pembelajaran pada pendidikan tinggi. Dari hasil penelusuran tersebut menghasilkan 25 artikel yang sesuai dalam penelitian artikel ini.

\section{HASIL DAN PEMBAHASAN}

\subsection{Kampus Merdeka}

Kampus Merdeka adalah salah satu kebijakan Menteri Pendidikan dan Kebudayaan. Ada dua konsep yang esensial dalam Kampus Merdeka, yaitu yang pertama konsep merdeka belajar mengandung arti adanya kemerdekaan berpikir. Menurut Nadiem Makarim bahwa esensi kemerdekaan berpikir harus dimulai terlebih dulu oleh para pendidik. Pandangan seperti ini harus dilihat sebagai salah satu upaya untuk menghormati perubahan dalam pembelajaran di lembaga Pendidikan baik di sekolah dasar hingga perguruan tinggi.

Kedua, kampus merdeka merupakan kelanjutan dari konsep merdeka belajar. Kampus merdeka merupakan upaya untuk melepaskan belenggu untuk bisa bergerak lebih mudah. Arti kampus merdeka adalah:

a. Hak belajar selama tiga semester di luar program studi. Perguruan tinggi wajib memberikan hak untuk mahasiswa secara sukarela mengambil atau tidak di luar perguruan tingginya sebanyak dua semester atau setara dengan 40 SKS. Selanjutnya, mahasiswa juga dapat mengambil sks di prodi lain di dalam kampus sebanyak satu semester.

b. Kebebasan bagi perguruan tinggi negeri BLU (Badan Layanan Umum) dan Satker (Satuan Kerja) untuk menjadi PTN BH (Perguruan Tinggi Negeri Badan Hukum).

c. Adanya otonomi perguruan tinggi baik perguruan tinggi negeri maupun swasta.

d. Program re-akreditasi otomatis.

Hak belajar tiga semester di luar program studi merupakan kebijakan pemerintah agar menyiapkan kompetensi mahasiswa menghadapi perubahan sosial, budaya, dunia industri dan kemajuan teknologi yang begitu pesat. Kompetensi mahasiswa harus disesuaikan dengan tuntutan zaman yang mengalami perubahan tersebut sehingga adanya link and match dengan dunia industri dan dunia kerja serta masa depan. Dalam Permendikbud 3, 2020 tentang Standar Nasional Pendidikan Tinggi menyatakan bahwa:

1. Bentuk pembelajaran dilakukan dalam program studi dan di luar program studi.

a. Pembelajaran dalam program studi lain pada perguruan tinggi yang sama;

b. Pembelajaran dalam program studi yang sama pada perguruan tinggi yang berbeda; 
c. Pembelajaran dalam program studi lain pada perguruan tinggi yang berbeda;

d. Pembelajaran pada lembaga non perguruan tinggi.

2. Proses pembelajaran di luar program studi dilaksanakan berdasarkan perjanjian kerjasama antara perguruan tinggi dengan perguruan tinggi atau lembaga lain yang terkait dan hasil kuliah diakui melalui mekanisme transfer Satuan Kredit Semester.

3. Proses pembelajaran di luar program studi dilaksanakan di bawah bimbingan dosen.

4. Proses pembelajaran di luar program studi ditentukan oleh Kementrian dan/atau pemimpin perguruan tinggi.

Tujuan kampus merdeka ini adalah untuk meningkatkan komptensi lulusan, baik secara soft skills maupun hard skills agar lebih siap dan relevan dengan kebutuhan zaman, menyiapkan lulusan sebagai pemimpin masa depan bangsa yang unggul dan berkepribadian. Bentuk kegiatan pembelajaran mengacu pada Permendikbud No. 3 Tahun 2020 Pasal 15 Ayat 1 dinyatakan dapat dilakukan di dalam program studi dan di luar program studi yang meliputi:

1. Pertukaran pelajar

2. Magang/Praktik Kerja

3. Membangun Desa/Kuliah Kerja Nyata Tematik (KKNT)

\subsection{Paradigma Dalam Pendidikan: Paradigma Pengajaran dan Pembelajaran}

Dengan adanya globalisasi dan reformasi, terjadi perubahan paradigma pendidikan. Pertama, paradigma proses pendidikan yang berorientasi pada pengajaran dimana guru lebih menjadi pusat informasi, bergeser pada proses pendidikan yang berorientasi pada pembelajaran dimana peserta didik menjadi sumber (student center). Kedua, paradigma proses pendidikan tradisional yang berorientasi pada pendekatan klasikal dan format di dalam kelas, bergeser ke model pembelajaran yang lebih fleksibel, seperti pendidikan dengan sistem jarak jauh. Ketiga, mutu pendidikan menjadi prioritas (berarti kualitas menjadi internasional). Keempat, semakin populernya pendidikan seumur hidup dan makin mencairnya batas antara pendidikan di sekolah dan di luar sekolah.

Menurut (Barr R. B and Tagg J, 1995), mengatakan bahwa pergeseran paradigma ini menjadikan kampus sebagai lembaga yang hadir untuk menghasilkan pembelajaran. Pergeseran ini membebaskan lembaga dari berbagai rangkaian kesulitan yang berkaitan dengan penyelenggaraan pengajaran karena misi lembaga adalah menghasilkan pembelajaran yang diikuti oleh seluruh mahasiswa melalui upaya-upaya terbaik dari mereka. Paradigma pembelajaran memberikan kesempatan pada para mahasiswa untuk menetapkan batas-batas pembelajaran dan keberhasilannya, sedangkan paradigma pengajaran berupaya mencapai keberhasilan atas apa yang telah ditetapkan lembaga dengan mengembangkan metode pengajaran tertentu.

Menurut (Nichols, 2013), menjelaskan tentang empat prinsip pembelajaran abad ke-21. Yaitu, instruction should be student centered (pembelajaran berpusat pada siswa); education should be collaborative (pendidikan yang kolaboratif); learning should have context (pembelajaran yang kontekstual); dan schools should be integrated with society (integrasi sosial). Pengembangan pembelajaran menggunakan pendekatan pembelajaran yang berpusat pada peserta didik. Peserta didik ditempatkan sebagai subyek pembelajaran yang secara aktif mengembangkan minat dan potensi yang dimilikinya.

Pembelajaran berpusat pada peserta didik bukan berarti menyerahkan kendali belajar sepenuhnya kepada peserta didik. Intervensi masih diperlukan dan pendidik berperan sebagai 
fasilitator yang berupaya membantu mengaitkan pengetahuan awal (prior knowledge) yang telah dimiliki peserta didik dengan informasi baru yang akan dipelajarinya. Memberi kesempatan pada peserta didik untuk belajar sesuai dengan cara dan gaya belajarnya masingmasing dan mendorong mereka untuk bertanggung jawab atas proses belajar yang dilakukannya. Selain itu, pendidik juga berperan sebagai pembimbing, yang berupaya membantu peserta didik ketika menemukan kesulitan dalam proses mengkonstruksi pengetahuan dan keterampilannya.

\section{Kesimpulan}

Menurut (Huynh TL, 2020), Pembelajaran selalu berkembang seiring dengan perubahan zaman, dengan model pembelajaran yang diterapkan di perguruan tinggi. Terlebih lagi dengan adanya pandemi Covid-19 pembelajaran dituntut untuk melakukan penyesuaian. Dengan adanya pemberdayaan sumber daya manusia dan peningkatan produktifitas yang dilakukan, khususnya pada pendidikan tinggi, dibutuhkan cara pandang baru untuk melakukan perubahan kegiatan pembelajaran untuk dapat mencapai tujuan pendidikan secara efektif. Hal ini yang menjadikan Pendidikan tinggi harus mampu untuk menyediakan dan menghasilkan pembelajaran-pembelajaran yang inovatif dan lebih produktif serta berdaya saing.

Persaingan dalam globalisasi memunculkan suatu era baru yaitu era ekonomi berbasis pengetahuan yang mensyaratkan kreativitas, inovasi, kompetensi dan daya saing. Hal ini menjadi tantangan bagi dunia pendidikan dalam menghasilkan lulusannya. Keterbukaan dan kecepatan akses informasi menjadi bagian yang tidak terpisahkan dalam lingkungan pendidikan. Semua tantangan tersebut harus terintegrasi pada satu sosok manusia modern yang dapat dihasilkan oleh perguruan tinggi sebagai lembaga pendidikan formal pada level akhir. Tantangan ini perlu di sikapi dengan langkah awal melakukan perubahan paradigma dalam pembelajaran.

Terlepas dari adanya pandemi Covid-19, pembelajaran jarak jauh sejatinya adalah misi pemerintah dalam mewujudkan kemerdekaan belajar. Salah satu tujuan dari program merdeka belajar adalah memberikan kemudahan bagi pelajar agar dapat belajar sepanjang hayat tanpa terkendala ruang dan waktu (Abidah, A., Hidaayatullaah, H. N., Simamora, R. M., Fehabutar, D., \& Mutakinati, 2020), oleh karena itu semua perguruan tinggi dituntut untuk melakukan perubahan, termasuk dalam hal ini adalah perubahan model pembelajaran.

Dengan adanya kampus merdeka bertujuan untuk meningkatkan komptensi lulusan, baik soft skills maupun hard skills menyiapkan mahasiswa lebih siap dan relevan dengan kebutuhan perkembangan zaman, menyiapkan lulusan sebagai pemimpin masa depan bangsa yang unggul dan berkepribadian. Sehingga dengan adanya kampus merdeka dapat memberikan keleluasaan kepada mahasiswa untuk memilih aspek pengembangannya sesuai dengan kerja sama mitra yang telah dirancang oleh program asal mahasiswa. Program ini diharapkan memberikan pengalaman baru kepada mahasiswa untuk memilih program sesuai dengan karakteristik dan minatnya, mendorong motivasi mahasiswa, menjadikannya alumni yang berdaya guna bagi kehidupan dan masyarakat di sekitarnya.

\section{Daftar Pustaka}

Abidah, A., Hidaayatullaah, H. N., Simamora, R. M., Fehabutar, D., \& Mutakinati, L. (2020). The Impact of Covid-19 to Indonesian Education and Its Relation to the Philosophy of "Merdeka Belajar". Studies in Philosophy of Science and Education, 38-49. 
Huynh TL. (2020). The COVID-19 risk perception: A survey on socioeconomics and media attention. Economics Bulletin. . AccessEcon, 40(1(1), 758-764.

J, B. R. B. and T. (1995). FROM LEARNING TO TEACHING - A New Paradigm for Undergraduate Education. Magazine of Higher Learning. Volume 27, Issue 6, 1995.

Kemendikbud. (2020). Mendikbud Luncurkan Empat Kebijakan Merdeka Belajar: Kampus Merdeka. Kementerian Pendidikan Dan Kebudayaan.

Kuhn, T. S. (1996). The Structure of Scientific Revolution.

Mendikbud RI. (2020). Peraturan Menteri Pendidikan Dan Kebudayaan Republik Indonesia Nomor 3 Tahun 2020 Tentang Standar Nasional Pendidikan Tinggi. Menteri Pendidikan Dan Kebudayaan RI, 1-76.

Nichols, J. R. (2013). No Title. 4 Essential of 21st Century Learning.

Pemerintah Republik Indonesia. (2012). UU No 12 Tahun 2012 tentang Pendidikan Tinggi. Republik Indonesia.

Permendikbud 3, P. R. 3. (2020). Peraturan Menteri Pendidikan Dan Kebudayaan Republik Indonesia Nomor 3 Tahun 2020 Tentang Standar Nasional Pendidikan Tinggi. Menteri Pendidikan Dan Kebudayaan RI.

UU No 20 Tahun 2003 Tentang Sistem Pendidikan Nasional pada Pasal, Kemendiknas (2003).

Ritzer, G. (1975). Sociology a Multiple Paradigm Science. Boston : Allyn and Bacon.

Suhartoyo, E., Wailissa, S. A., Jalarwati, S., Samsia, S., Wati, S., Qomariah, N., Dayanti, E., Maulani, I., Mukhlish, I., Rizki Azhari, M. H., Muhammad Isa, H., \& Maulana Amin, I. (2020). Pembelajaran Kontekstual Dalam Mewujudkan Merdeka Belajar. Jurnal Pembelajaran Pemberdayaan Masyarakat (JP2M), 161. https://doi.org/10.33474/jp2m.v1i3.6588

Suwignyo, A. (2013). The Great Depression and the changing trajectory of public education policy in Indonesia, 1930-42. Journal of Southeast Asian Studies, 44(3), 465-489. https://doi.org/10.1017/S0022463413000337 